\title{
PATTERNS OF CLINICAL MANAGEMENT OF ATOPIC ECZEMA AMONG DERMATOLOGISTS AND OTHER SPECIALTIES
}

\author{
By \\ Amal A Kokandi \\ Department of Dermatology, Faculty of Medicine, King Abdulaziz University, Saudi \\ Arabia
}

\begin{abstract}
Background: Eczema is a common chronic skin disease with varying severities. Dermatologists and other specialties share the management of this disease including general physicians, pediatricians, immunologists and others.
\end{abstract}

Objectives: to explore the eczema management strategy differences between dermatologists and other specialties at Saudi Arabia.

Methods: An anonymous online questionnaire was sent to dermatologists and other specialties. The questionnaire included questions about eczema management strategies and opinions.

Results: All specialties advised the use of moisturizers and the avoidance of irritants. However, there were few differences among specialties. Immunologists were less likely to prescribe topical corticosteroids and more likely to check vitamin D. Immunologists and pediatricians are the highest in ordering $\operatorname{IgE}$ and specific IgE for food and aeroallergen tests in their practice.

Conclusion: Eczema management in our area has few discrepancies between specialties of dermatology, immunology, pediatrics, medicine and family medicine.

Key words: Eczema, dermatologists, topical corticosteroids, non-dermatologists.

\section{INTRODUCTION}

Eczema is a common chronic skin disease. The management is long term and involves many approaches. Skin care with emollients is an important element of the care. Eczema has a burden on the patient and care givers and patients may be undertreated half of the time they are in flare (Zuberbier et al., 2006). Treatment of skin inflammation, infections, itch amelioration, treatment of associated morbidities and others are needed according to the severity and extent of the disease. Approximately, two thirds of cases are mild and can be treated at the primary care level.

There are few discrepancies in the guidelines for the management strategy for this disease between dermatologists and other specialties (Saavedra et al., 2013 and Mohan et al., 2015). Previous study showed that there is a discrepancy between dermatologist, pediatrician and family physicians in managing atopic dermatitis in children (Resnick et al., 1996). In addition, dermatologists at different countries have different approaches toward managing the disease 
as well (Baron et al., 2001).In addition to dermatologists, other specialties share in management of eczema including pediatricians, medical and allergists immunologists which were referred as immunologists in this paper (Eichenfield et al., 2015).

The aim of this study was to explore the eczema management strategy differences between dermatologists and other specialties through an online questionnaire.

\section{METHODS}

An electronic invitation to participate in the study was sent by e-mails and social media (Whats App application) to groups of dermatologists, family physicians, pediatricians and allergist, immunologists in western area of Saudi Arabia during the period from June 2015 to December 2016. The invitation contained a link to the survey questionnaire. It was administered through Monkey survey tool, and it was anonymous. No identifying information was collected as internet protocol (IP) addresses or email addresses. The questionnaire included questions about eczema management strategies or plans with 5 choices of always, sometimes, depending on case severity, rarely and never.

The study protocol was approved by the unit of biomedical ethics research committee at King Abdulaziz university Hospital (Reference No 146-16).

Data were analyzed using SPSS software (version 21). A first KruskalWallis test was performed on all the groups together. The main effects were reported first, followed by Kruskal-Wallis analysis for every 2 groups. Two sided $\mathrm{P}$ values of 0.05 or less were considered statistically significant. Data were represented as mean $\pm \mathrm{SE}$. All missing data were classed as missing at random and only available data were analyzed.

\section{RESULTS}

In total, 98 responses were received. Responses with no in the question of do you see and manage eczema patients and incomplete responses (no responses in the management questions) were not included in the analysis of data. Seventy two responses were eligible for analysis.

Data from the questionnaire was used to compare the frequency of medications prescribed and treatment management methods applied between dermatologists and other specialties. The questionnaire scale was marked from 1 to 5 as 1 indicated more likely and 5 indicated less likely. The mean of each point of the questionnaire was compared between specialties. The less the mean means the more likely the approach was applied by a specialty (Table 1).

Seeing and managing eczema patients were significantly more frequent in dermatologists' practice compared with other physicians except immunologists Dermatologists were significantly more likely to describe topical and oral antibiotics than other physicians except immunologists However, they are less likely to describe topical and oral antifungals than other physicians, and this difference is only significant when comparing to immunologists. The frequency of prescribing topical 
corticosteroids was significantly lower in immunologists compared with other physicians, but it was not significantly different between the other physicians.

Table (1): Eczema patient encountering and management among specialities

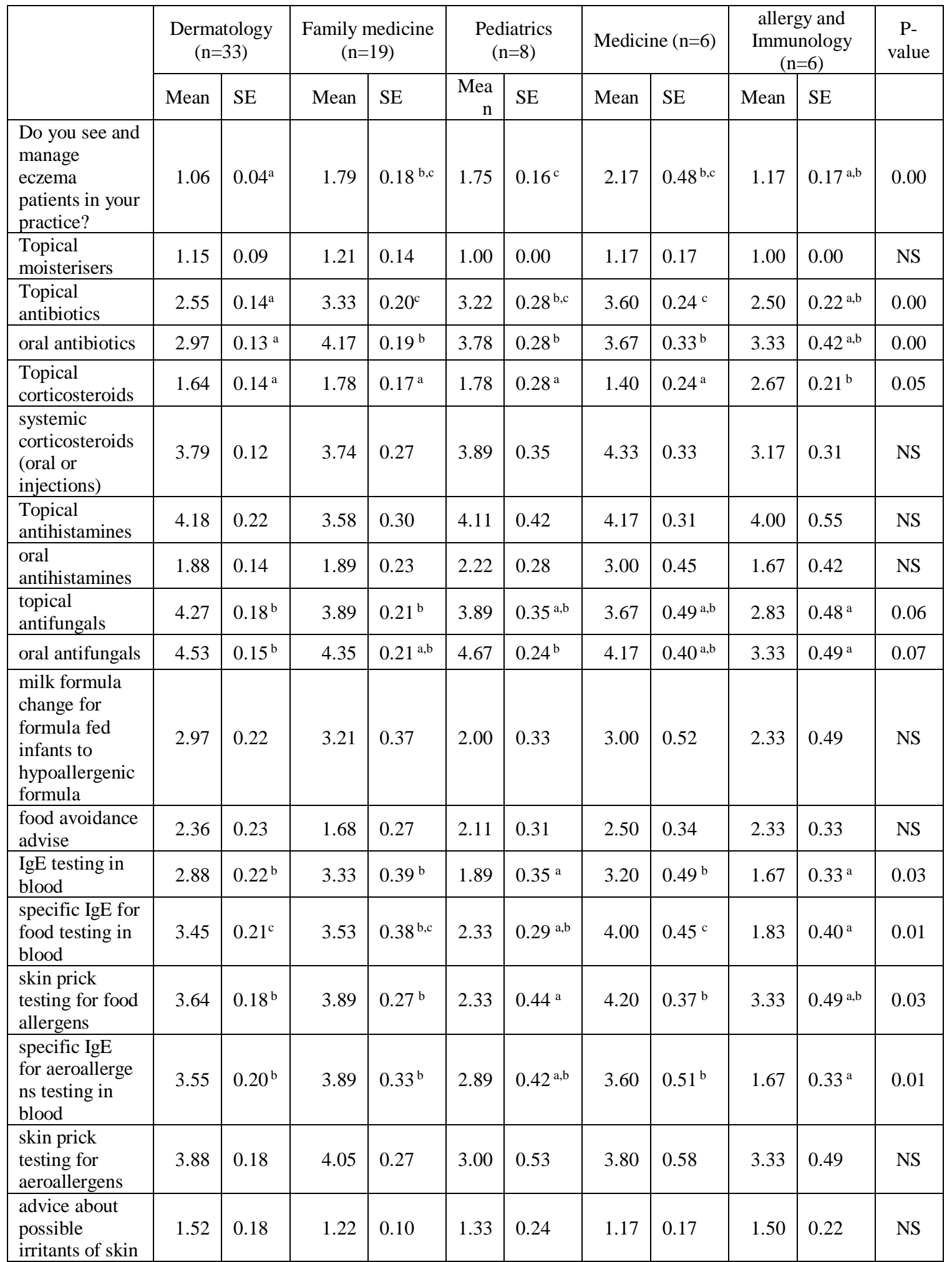


AMAL A KOKANDI

\begin{tabular}{|c|c|c|c|c|c|c|c|c|c|c|c|}
\hline $\begin{array}{l}\text { patch testing if } \\
\text { contact } \\
\text { dermatitis is } \\
\text { suspected }\end{array}$ & 3.55 & 0.21 & 3.84 & 0.31 & 4.56 & 0.24 & 2.80 & 0.73 & 4.00 & 0.45 & NS \\
\hline $\begin{array}{l}\text { open patch } \\
\text { testing for } \\
\text { possible } \\
\text { contact } \\
\text { allergens } \\
\end{array}$ & 4.42 & 0.14 & 4.11 & 0.27 & 4.89 & 0.11 & 3.80 & 0.58 & 4.33 & 0.49 & NS \\
\hline clothing advice & 1.36 & 0.12 & 1.11 & 0.07 & 1.00 & 0.00 & 1.50 & 0.34 & 2.00 & 0.63 & NS \\
\hline stress advice & 2.09 & 0.23 & 1.47 & 0.18 & 2.33 & 0.60 & 2.50 & 0.34 & 2.33 & 0.49 & NS \\
\hline $\begin{array}{l}\text { considering } \\
\text { immunotherap } \\
\text { y if needed }\end{array}$ & 3.21 & 0.16 & 3.68 & 0.32 & 3.56 & 0.47 & 4.00 & 0.63 & 2.83 & 0.48 & NS \\
\hline $\begin{array}{l}\text { order and } \\
\text { check full } \\
\text { blood count }\end{array}$ & 2.67 & $0.22^{\mathrm{b}}$ & 2.74 & $0.26^{\mathrm{b}}$ & 2.38 & $0.46^{\mathrm{a}, \mathrm{b}}$ & 1.80 & $0.20^{\mathrm{a}, \mathrm{b}}$ & 1.33 & $0.33^{\mathrm{a}}$ & 0.05 \\
\hline $\begin{array}{l}\text { order and } \\
\text { check vitamin } \\
\text { D }\end{array}$ & 3.33 & $0.26^{\mathrm{b}}$ & 3.47 & $0.30^{\mathrm{b}}$ & 3.22 & $0.46^{\mathrm{a}, \mathrm{b}}$ & 2.80 & $0.49^{b}$ & 1.50 & $0.34^{\mathrm{a}}$ & 0.05 \\
\hline $\begin{array}{l}\text { supplement } \\
\text { with omega } 3 \\
\text { fatty acids }\end{array}$ & 4.06 & 0.22 & 4.11 & 0.29 & 4.11 & 0.48 & 3.40 & 0.68 & 3.00 & 0.63 & NS \\
\hline $\begin{array}{l}\text { for adults } \\
\text { presenting for } \\
\text { the first time } \\
\text { considering } \\
\text { other } \\
\text { differential } \\
\text { diagnosis and } \\
\text { do lab work up }\end{array}$ & 2.12 & 0.16 & 2.37 & 0.29 & 3.11 & 0.59 & 1.60 & 0.24 & 1.60 & 0.24 & NS \\
\hline $\begin{array}{l}\text { advice using } \\
\text { natural oils like } \\
\text { olive oil }\end{array}$ & 3.42 & 0.24 & 2.74 & 0.34 & 2.33 & 0.44 & 3.17 & 0.70 & 3.00 & 0.63 & NS \\
\hline $\begin{array}{l}\text { explain the } \\
\text { nature of the } \\
\text { disease } \\
\text { regarding its } \\
\text { genetic } \\
\text { background }\end{array}$ & 1.34 & 0.12 & 1.63 & 0.23 & 1.33 & 0.17 & 1.40 & 0.24 & 1.50 & 0.50 & NS \\
\hline $\begin{array}{l}\text { explain the } \\
\text { nature of the } \\
\text { disease } \\
\text { regarding its } \\
\text { immunological } \\
\text { and allergic } \\
\text { background }\end{array}$ & 1.42 & 0.12 & 1.79 & 0.22 & 1.56 & 0.18 & 1.33 & 0.21 & 1.67 & 0.49 & NS \\
\hline $\begin{array}{l}\text { explain the } \\
\text { association } \\
\text { with other } \\
\text { diseases like } \\
\text { asthma and } \\
\text { allergic rhinitis }\end{array}$ & 1.27 & 0.11 & 1.32 & 0.13 & 1.33 & 0.17 & 1.17 & 0.17 & 1.67 & 0.49 & NS \\
\hline
\end{tabular}

$\mathrm{a}=$ significantly different than $\mathrm{B}$ and $\mathrm{C}, \mathrm{b}=$ significantly different than $\mathrm{A}$ and $\mathrm{C}$, and $\mathrm{c}=$ significantly different than $\mathrm{A}$ and $\mathrm{B}$

Immunologists and pediatricians are the highest in ordering $\operatorname{IgE}$ and specific $\mathrm{IgE}$ for food and aeroallergen tests in their practice. They order significantly more
$\operatorname{IgE}$ and specific IgE for food tests compared with other physicians. However, immunologists but not pediatric physicians have significantly higher 
orders of specific IgE for aeroallergen compared with other physicians $(\mathrm{P}<0.05$ at least). Pediatric physicians order skin prick testing for food allergens significantly more than other physicians except immunologists $(\mathrm{P}<0.05$ at least). The frequency of ordering $\operatorname{IgE}$ and specific IgE for food and aeroallergen and skin prick testing for food allergens was

\section{DISCUSSION}

Management of eczema relies mainly on topical moisturizers and control of itching and inflammation. In addition, it relies on treatment of infections, and management of associated problems such as other atopic features like asthma and food allergy.

Eczema patients are seen and managed by dermatologists usually, but other specialty physicians manage them as well. In this study, dermatologists and immunologists see eczema patients more frequently than family, medical physicians and pediatricians. So all specialties in this study were similar in making advice about possible irritants of skin, clothing advice, and explaining the nature of the disease regarding its genetic background. Additionally, all agreed on the importance of skin moisterisation. Topical antihistamines have no place in eczema management, and this was reflected in our study. On the other hand, oral antihistamines seem to be prescribed by all specialties. This is in line with previous recommendations (Mohan et al., 2015). Open patch test is not being used frequently by all specialties as well as supplementation with omega 3 fatty acids, natural oils, and considering immunotherapy . similar between dermatologists, family medicine and medicine physicians.

Immunologists were the highest in ordering and checking full blood count and vitamin D levels. They were significantly more likely to order these blood tests than dermatologists and family medicine physicians $(\mathrm{P}<0.05$ at least $)$.

Topical corticosteroids are the main topical pharmacotherapy used for eczema. In this study, it was less likely to be prescribed by immunologists than other specialties. This might be explained because immunologists think of eczema as a systemic disease so they do not rely very much on topical corticosteroids or the fact that they may usually see more severe cases than others. Previous study showed that dermatologists are more likely to recommend topical corticosteroids and especially higher potencies than other specialties (Henderson et al., 2001 and McGregor et al., 2017).

Regarding topical and oral antibiotics dermatologists and immunologists seemed to prescribe them more than other specialties. Antibiotics were used to treat skin infections in eczema. This finding could be due to more severe cases of eczema which were seen by dermatologists and immunologists. On the other hand, dermatologists were less likely to prescribe topical and oral antifungals in comparison to immunologists. This is might be reflecting more confidence of dermatologists in diagnosing fungal infections, while immunologists like to cover for suspicious lesions for fungal infections. The use of empirical antibiotic treatment in eczema is still controversial (Leung, 2016). 
Immunologists and pediatricians are more likely to do $\mathrm{IgE}$, specific $\operatorname{IgE}$ and skin prick testing for food allergens. In a previous study at USA, most pediatricians and allergists use formula change as a management strategy in some patients, whereas dermatologists favor a pharmacologic approach. The same study showed that immunologists use elimination diet with food challenge test more than dermatologists (Saavedra et al., 2013). Dermatologists are less likely to tell patients that allergy play a role in their disease (Thompson et al., 2006). On the other hand, allergists tend to test for IgE too frequently (Hanifin, 2012). In this study, immunologists and pediatricians do not attempt to do milk formula change or make food avoidance advice more than other specialties. One large cohort of infants at risk for development of food allergy, serum IgE levels were not clinically useful for predicting food allergy development (Spergel et al., 2015).

Immunologists and pediatricians were also more likely to check full blood count and vitamin D levels than others. This could reflect the difference in the guidelines regarding vitamin $\mathrm{D}$ use in eczema (Mohan et al., 2015). As the Joint Task Force on Practice Parameters, the American College of Allergy, Asthma\& Immunology., and the Joint Council of Allergy, Asthma \& Immunology (Schneider et al., 2013 and Lio et al., 2014) supports the use of vitamin D in comparison to other guidelines, namely The American Academy of Dermatology (Eichenfield et al., 2014a \& 2014b and Sidbury et al., 2014a and 2014b) The 2012 European Task Force on Atopic Dermatitis (Ring et al., 2012a and Ring et al., 2012b) and The 2013 Asia-Pacific Consensus Group for Atopic Dermatitis (Rubel et al., 2013).

Study limitations included the small number of participants and the need for more systematic representation of the sample study. This may warrant a larger study to explore the eczema management especially at primary health care level as the main management of mild cases take place.

\section{CONCLUSION}

Eczema management in our area has few discrepancies between specialties of dermatology, immunology, pediatrics, medicine and family medicine.

\section{ACKNOWLEDGEMENT}

To Sumia Enani (Assistant Professor in Nutritional Sciences) for her assistance in statistical analysis.

\section{CONFLICT OF INTEREST}

None declared.

\section{REFERENCES}

1. Baron, E.D., Barzilai, D., Johnston, G., Kawashima, M., Takigawa, M., Nakagawa, H., Graham-Brown, R.A. and Stevens, S.R (2001): Atopic dermatitis management: comparing the treatment patterns of dermatologists in Japan, U.S.A. and U.K. Br J Dermatol., 147(4): 710-715.

2. Eichenfield, L.F., Boguniewicz, M., Simpson, E.L., Russell, J.J., Block,J.K., Feldman, S.R., Clark, A.R., Tofte, S., Dunn, J.D. and Paller, A.S (2015): Translating Atopic Dermatitis Management Guidelines Into Practice for Primary Care Providers. Pediatrics, 136(3): 554-565.

3. Eichenfield, L.F., Tom, W.L., Berger, T.G, Krol, A., Paller, A.S., Schwarzenberger, K., Bergman, J.N., Chamlin, S.L., Cohen, D.E., Cooper, K.D., Cordoro, K.M., Davis, D.M., Feldman, S.R., Hanifin, J.M., Margolis, D.J., 
Silverman, R.A., Simpson, E.L., Williams, H.C., Elmets, C.A., Block, J., Harrod, C.G., Smith Begolka, W. and Sidbury, R (2014a): Guidelines of care for the management of atopic dermatitis, section 2: management and treatment of atopic dermatitis with topical therapies. J Am AcadDermatol., 71(1): 116132.

4. Eichenfield, L.F., Tom, W.L., Chamlin, S.L., Feldman, S.R., Hanifin, J.M., Simpson, E.L., Berger, T.G., Bergman, J.N., Cohen, D.E., Cooper, K.D., Cordoro, K.M., Davis, D.M., Krol, A., Margolis, D.J., Paller, A.S, Schwarzenberger, K., Silverman, R.A., Williams, H.C., Elmets, C.A., Block, J., Harrod, C.G., Smith Begolka, W. and Sidbury, R (2014b): Guidelines of care for the management of atopic dermatitis, section 1: diagnosis and assessment of atopic dermatitis. $\mathbf{J}$ Am AcadDermatol., 70(2): 338-351.

5. Hanifin, J.M (2012): Atopic dermatitis nomenclature variants can impede harmonization. J Invest Dermatol., 132(2): 472473.

6. Henderson, R.L., Fleischer, A.B. and Feldman, S.R (2001): Dermatologists and allergists have far more experience and use more complex treatment regimens in the treatment of atopic dermatitis than other physicians. J Cut Med Surg., 5(3): 211-216.

7. Leung, T.F (2016): Antibiotics of no benefit to children with eczema and features of cutaneous infection but controversy remains unresolved. Evidence-Based Medicine, 21: 179-182.

8. Lio, P.A., Lee, M.,LeBovidge, J., Timmons, K.G. and Schneider, L (2014): Clinical management of atopic dermatitis: practical highlights and updates from the atopic dermatitis practice parameter 2012. J Allergy ClinImmunolPract., 2(4): 361-370.

9. McGregor, S.P., Farhangian, M.E., Huang, K.E. and Feldman, S.R (2017): Treatment of atopic dermatitis in the United States: analysis of data from the National Ambulatory Medical Care Survey. J Drugs Dermatol., 16(3): 250255.

10. Mohan, G.C. and Lio, P.A (2015): Comparison of Dermatology and Allergy
Guidelines for Atopic Dermatitis Management. JAMA Dermatology, 151(9): 1009-1013.

11. Resnick, S.D., Hornung, R. and Konrad, T.R (1996): A comparison of dermatologists and generalists. Management of childhood atopic dermatitis. Arch Dermatol., 132(9): 1047-1052.

12. Ring. J., Alomar, A., Bieber, T., Deleuran, M., Fink-Wagner, A., Gelmetti, C., Gieler, U., Lipozencic, J., Luger, T., Oranje, A.P., Sch?fer, T., Schwennesen, T., Seidenari, S., Simon, D., St?nder, S., Stingl, G., Szalai, S., Szepietowski, J.C., Taïeb, A., Werfel, T., Wollenberg, A. and Darsow, U (2012a):Guidelines for treatment of atopic eczema (atopic dermatitis), part I. J EuropAcadDermatolVenereol., 26(8): 10451060.

13. Ring. J., Alomar, A., Bieber, T., Deleuran, M., Fink-Wagner, A.,Gelmetti, C., Gieler, U., Lipozencic, J., Luger, T., Oranje, A.P., Sch?fer, T., Schwennesen, T., Seidenari, S., Simon, D., St?nder, S., Stingl, G., Szalai, S., Szepietowski, J.C., Taïeb, A., Werfel, T., Wollenberg, A. and Darsow, U (2012b):Guidelines for treatment of atopic eczema (atopic dermatitis), part II. J EuropAcadDermatolVenereol., $\quad$ 26(9):11761193.

14. Rubel, D., Thirumoorthy, T., Soebaryo, R.W., Weng, S.C., Gabriel, T.M., Villafuerte, L.L., Chu, C.Y., Dhar, S., Parikh, D., Wong, L.C. and Lo, K.K (2013): Consensus guidelines for the management of atopic dermatitis: an Asia-Pacific perspective. J Dermatol., 40(3): 160-171.

15. Saavedra, J.M., Boguniewicz, M., Chamlin, S., Lake, A., Nedorost, S., Czerkies, L.A., Patel, V., Botteman, M.F. and Horodniceanu, E.G (2013): Patterns of clinical management of atopic dermatitis in infants and toddlers: a survey of three physician specialties in the United States. J Pediatr., 163(6): 1747-1753.

16. Schneider, L., Tilles, S., Lio, .P., Boguniewicz, M., Beck, L., LeBovidge, J., Novak, N., Bernstein, D., Blessing-Moore, J., Khan, D., Lang, D., Nicklas, R., Oppenheimer, J., Portnoy, J., Randolph, C., 
Schuller, D., Spector, S., Tilles, S. and Wallace, D (2013): Atopic dermatitis: a practice parameter update 2012. J Allergy ClinImmunol., 131(2): 295-299.e1-27.

17. Sidbury, R., Davis, D.M., Cohen, D.E., Cordoro, K.M., Berger, T.G., Bergman, J.N., Chamlin SL, Cooper, K.D., Feldman, S.R., Hanifin, J.M., Krol, A., Margolis, D.J., Paller, A.S., Schwarzenberger, K., Silverman, R.A., Simpson, E.L., Tom, W.L., Williams, H.C., Elmets, C.A., Block, J., Harrod, C.G., Begolka, W.S. and Eichenfield, L.F (2014a): Guidelines of care for the management of atopic dermatitis, section 3: management and treatment with phototherapy and systemic agents. J Am Acad Dermatol., 71 (2): 327-349

18. Sidbury, R., Tom, W.L., Bergman, J.N., Cooper, K.D., Silverman, R.A., Berger, T.G., Chamlin, S.L., Cohen, D.E., Cordoro, K.M., Davis, D.M., Feldman, S.R., Hanifin, J.M., Krol, A., Margolis, D.J., Paller, A.S., Schwarzenberger, K., Simpson, E.L., Williams, H.C., Elmets, C.A., Block, J., Harrod, C.G., Smith Begolka, W. and
Eichenfield, L.F (2014b): Guidelines of care for the management of atopic dermatitis, section 4: prevention of disease flares and use of adjunctive therapies and approaches. $\mathrm{J}$ Am Acad Dermatol., 71(6): 1218-1233.

19. Spergel, J.M., Boguniewicz, M., Schneider, L., Hanifin, J.M., Amy S., Paller, A.S. and Eichenfield, L.F (2015): Food Allergy in Infants with Atopic Dermatitis: Limitations of Food-Specific IgE Measurements. Pediatrics., 136(6): 1530-1538.

20. Thompson, M.M., Tofte, S.J., Simpson, E.L. and Hanifin, J.M (2006): Patterns of care and referral in children with atopic dermatitis and concern for food allergy. DermatolTher., 19(2): 91-96.

21. Zuberbier, T., Orlow, S.J., Paller, A.S., Taïeb, A., Allen, R., Hernanz-Hermosa, J.M., Ocampo-Candiani, J., Cox, M., Langeraar, J. and Simon, J.C (2006): Patient perspectives on the management of atopic dermatitis. J Allergy ClinImmunol., 118(1): 226-232. 


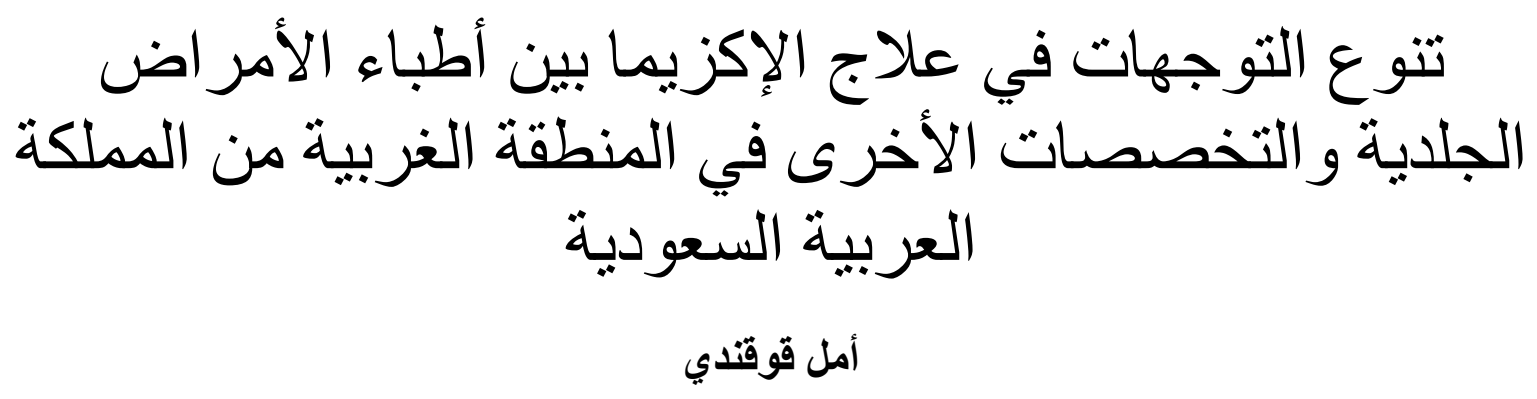

قسم الأمر اض الجلديةـ كلية الطب- جامعة الملك عبدالعزيز ـ المملكة العربية السعودية

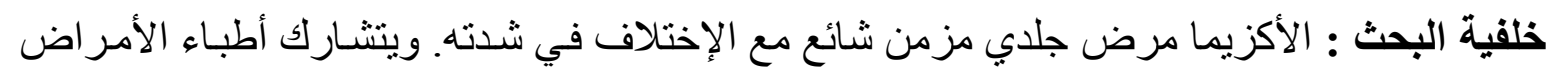

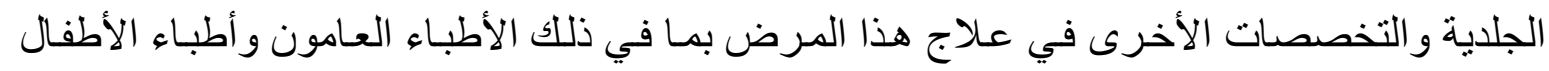

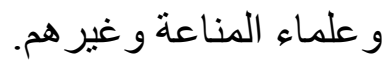

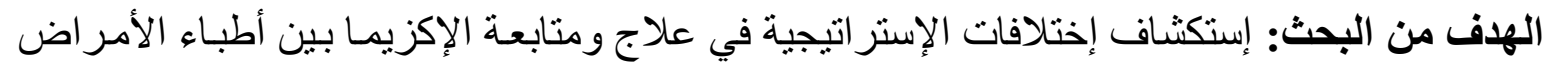
الجلدية والتخصصات الأخرى في المنطقة الغربية من المملكة العربية السعودية.

طريقة البحث: تم إرسال استبيان عبر الإنترنت إلى أطباء الأمر اض الجلدية والتخصصـات الأخرى و الذي تضمن أسئلة حول إستر اتيجيات وآراء الأطباء في علاج الإكزيما.

النتائج: نصح جميع المشاركين في البحثباستخدام المرطبات وتجنب المهيجات. ومع ذلك ، كانت هناك

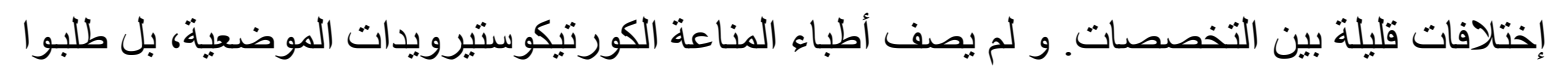

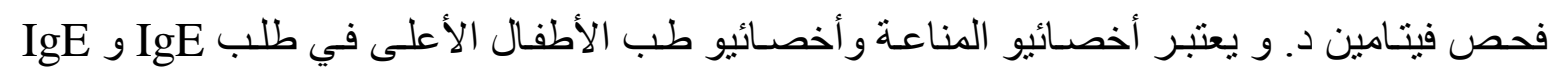
المعيّن في إختبار ات الغذاء و المحسنسات الهو ائية في ممارستهم.

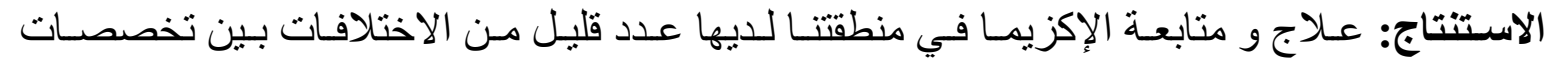
الأمر اض الجلدية ، و علم المناعة و طب الأطفال و الأمر اض الباطنية وطب الأسرة الأسرة. 